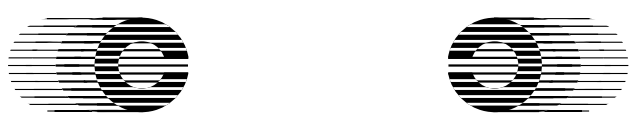

線虫 C. elegansにおける感覚情報の 統合と学習にかかわる
分子メカニズム

国立遺伝学研究所構造遺伝学研究センター 総合研究大学院大学遺伝学専攻 石原 健

\section{1.はじめに}

動物は, 環境からさまざまな刺激 (情報) を受容して いる. 脳・神経系は, 兴の中から状況に応じて必要な情 報を選択・抽出し, 適切に処理して行動を決定してい る. 乥の過程で, 情報は過去の経験や記憶などに応じて 適切な修飾を受ける場合がある. 高等生物では, このよ うな処理過程を非常に複雑に組み合わせて, 高度な神 経活動を行い行動していると考えられる. このような 情報処理のメカニズムを分子レベルで明らかにするこ とは, 神経回路の機能, ひいては脳の機能を理解するう えで重要なことである. 我々は, このような複雑な神経 機能を明らかにすることをめざして, 単純な神経系を もつ線虫Caenorhabditis elegans をモデルとして研究を 行っている.

C. elegans の雌雄同体の成虫の959個の体細胞のうち 302 個が神経細胞であり,生きたまま微分干涉顕微鏡で 観察可能である ${ }^{1), 21}$.これらの神経細胞からなる回路の 全構造は電子顕微鏡により明らかにされ, 約 5000 の化 学シナプス, 約 600 のギャップジャンクションにより回 路を形成していることが示された ${ }^{3)}$.また, 行動の解析 が比較的容易で, 遺伝学により行動と分子とを結びつ けることが可能である. さらに, ゲノムの全塩基配列も 決定されている4).このように線虫は, 行動をつかさど る神経回路における情報処理機構について, 分子・細

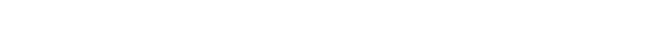

に適したモデル生物である.

\section{C. elegansにおける行動の解析}

C. elegansにおいては, 運動, 化学走性, 温度走性, 接 触來激忌避応答などのさまざまな行動5), 6) に関する研 究が, おもに2つの方法て進められてきた. 1つは, 特定 の神経細胞をレーザー破壊した線虫の行動を解析し， その行動における神経の機能を明らかにするというア プローチである. たとえば, 特定の感覚神経をレーザー で破壞し, 誘引性匂い物質に対する化学走性を調べる ことにより,AWA とAWCとよばれる2対の感覚神経 が, 匂い物質を受容していることが示された7).もう 1 つは, 特定の遺伝子に異常をもつために行動異常を示 すような変異体を解析することにより，乥の行動を制 御する分子メカニズムを明らかにするというアプロー チである. 薬阂などにより突然変異を誘起した線虫を, 誘引性匂い物質に対する化学走性を指標にしたスクリ ーニングにより得られた変異体の解析から, 匂い受容 感覚神経 (AWA, AWC) の分化や細胞内のシグナル伝 達機構が明らかになつた77), 8). しかし, 遺伝学的解析に おいては強い表現型を示す変異体が同定しやすいため, 比較的単純な行動である化学走性を指標にした場合, おもに感覚神経に異常がある変異体が単離・解析され ることとなった. 一方, 感覚情報の神経回路上での情報 処理に異常を示す変異体では, 化学走性における表現 型が弱く同定されにくかったと考えられる.

このように, 行動を指標として神経系の解析を行うう えでは, どのような行動に着目して解析を進めるかが 重要である ${ }^{10)}$. 我々は,“2 2つの入力から 1 つの出力” と いう最も単純な情報処理の1つとして, 情報の統合にか かわる行動に着目して遺伝学的解析をすすめ, 情報処 理の制御の分子機構の一端を明らかにしたのて紹介し たい11).

\section{3 . 感覚情報統合の行動測定系}

C. elegansは, ジアセチル (2,3-butanedione, バターの ような香り) などの匂い物質に正の走化性を示し7), 銅 イオンなどの重金属イオンを忌避する ${ }^{12}$. 細胞破壤実験

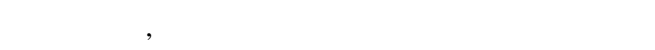
なっている (Fig.1B) ことか知られている.我々は,この 2つの刺激を用いて感覚情報の統合を測定する行動測

\title{
Molecular Mechanisms Involved in Sensory Integration and Learning in C. elegans
}

Takeshi ISHIHARA

Structural Biology Center, National Institute of Genetics, Department of Genetics, The Graduate University for Advanced Studies 

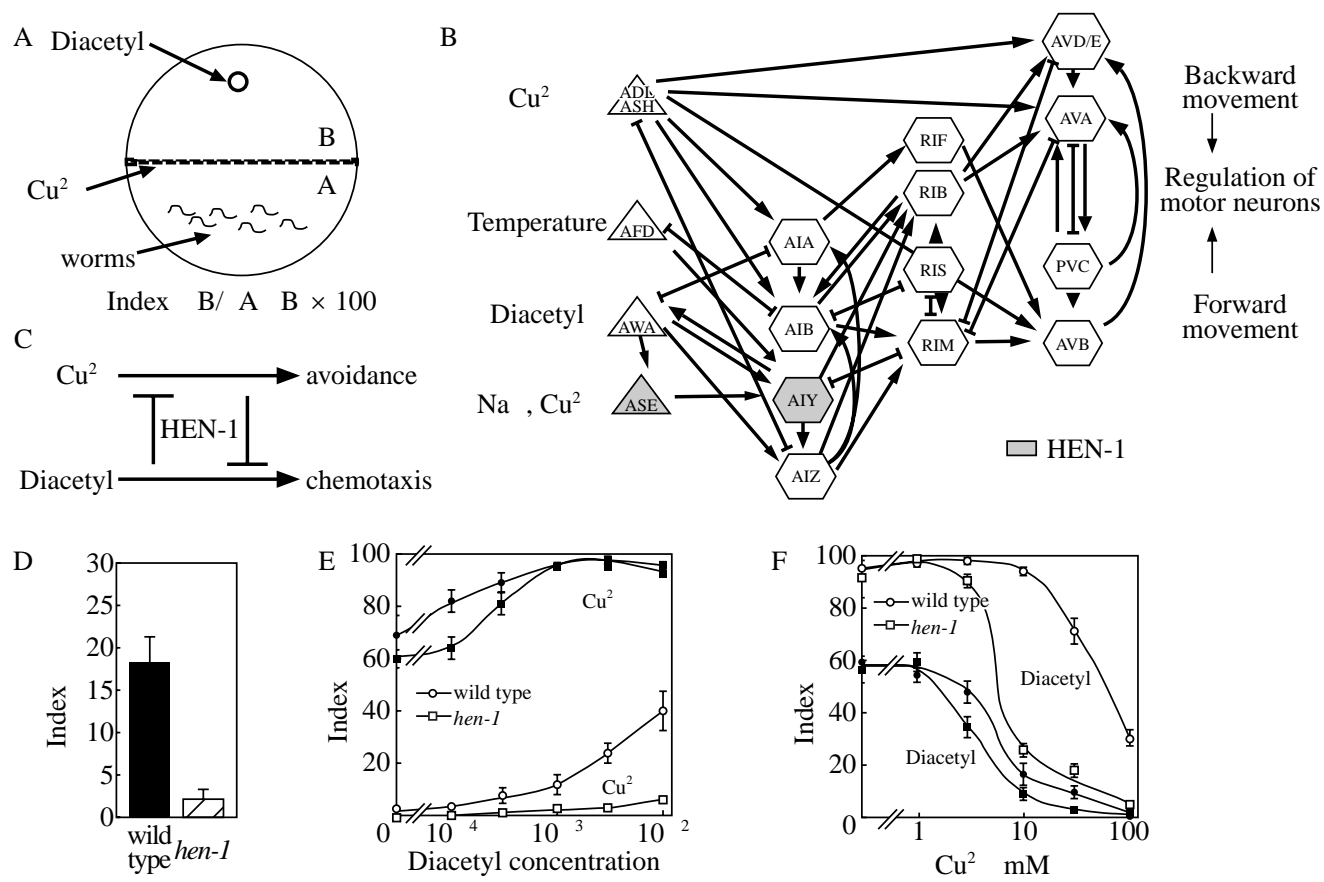

Fig.1 The interaction assay for the sensory integration and a phenotype of hen-1 in the assay ${ }^{11}$. A : Copper acetate solution was spread on the midline of the assay plate. After $18-22 \mathrm{hr}$, various concentration of diacetyl was spotted on the one side and about 50 worms were put on another side. After $90 \mathrm{~min}$, index was calculated. B: Putative neuronal circuit for the interaction of two sensory signals and for two types of behavioral plasticity. Triangles and hexagons represent sensory neurons and interneurons, respectively. Arrows represent chemical synapses and their direction, and $\mathrm{H}$ shapes represent gap junctions. The neurons expressing the HEN-1 protein are shaded. C : The sensory signal of chemotaxis toward diacetyl and that of the avoidance of $\mathrm{Cu}^{2+}$ ion inhibit each other. $\mathrm{D}$ : hen-1 animals showed weaker tendency to go over the $\mathrm{Cu}^{2+}$ barrier to the diacetyl than wild type animals. E, F : The phenotypes of the wild type and hen-1 in the interaction assay. Dose response curves of wild type and hen-1 to diacetyl with $(+)$ or without $(-) 100 \mathrm{mM} \mathrm{Cu}^{2+}$ ion and to $\mathrm{Cu}^{2+}$ ion with $(+)$ or without ( - ) $10^{-2}$ diacetyl.

定系 (interaction assayとよぶ)を開発した (Fig.1A). 寒天培地の中央に銅イオンを塗り, 光の片側に匂い物 質を, 弚の反対側に線虫をおき, 90 分後に光れ光れの側 の虫の数を数える. この測定では, 匂い物質と銅イオ ンの濃度に依存して, どれだけの線虫が匂い物質の 側へ動くかか変わることから, これらの感覚情報の間 にはお互いの出力を抑制する仕組みがあると考えられ る (Fig.1C). また, 匂い物質に対する走化性や銅イオン からの忌避反応の光れ光れに関しては精度良く測定す る方法か確立されており, この測定系での行動変異体 に感覚受容の異常があるかどうかが容易に調べられる. したがって,この測定系を用いることによって,“2つの 入力から 1 つの出力” という情報処理過程を, 感覚入力 の異常と切り離して解析できる. これまでの感覚神経 のマッピング7), 12) と神経の回路図 ${ }^{3)}$ から,この行動は 感覚神経を含めて十数対からなる微小な神経回路によ
り制御されていると推定できる (Fig.1B).

\section{4. hen-1変異体の情報の統合と学習にかかわる 表現型}

我々は, 感覚情報の統合の行動測定系において, 銅イ オンを越えて包い物質のほうへ行きにくい変異体hen-1 を同定した (Fig.1D) . hen-1 変異体は銅イオンからの

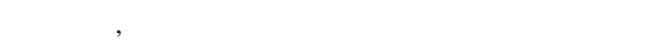
れには, 異常がみられなかった. しかし, 銅イオンと匂い 物質の両者の存在下で行動を測定した場合にのみ, 野 生型に比へ銅イオンからの忌避反応が優先され, 大きな 差がみられた (Fig.1E, Fig.1F). これらの結果は, hen-1 变異体が, ジアセチルと銅イオンに対する感覚受容に は異常がみられないが, これらの2つの情報の統合には 異常があることを示している (Fig.1C).

感覚情報の統合に異常があるhen-1 変異体には, $2 \supset$ 

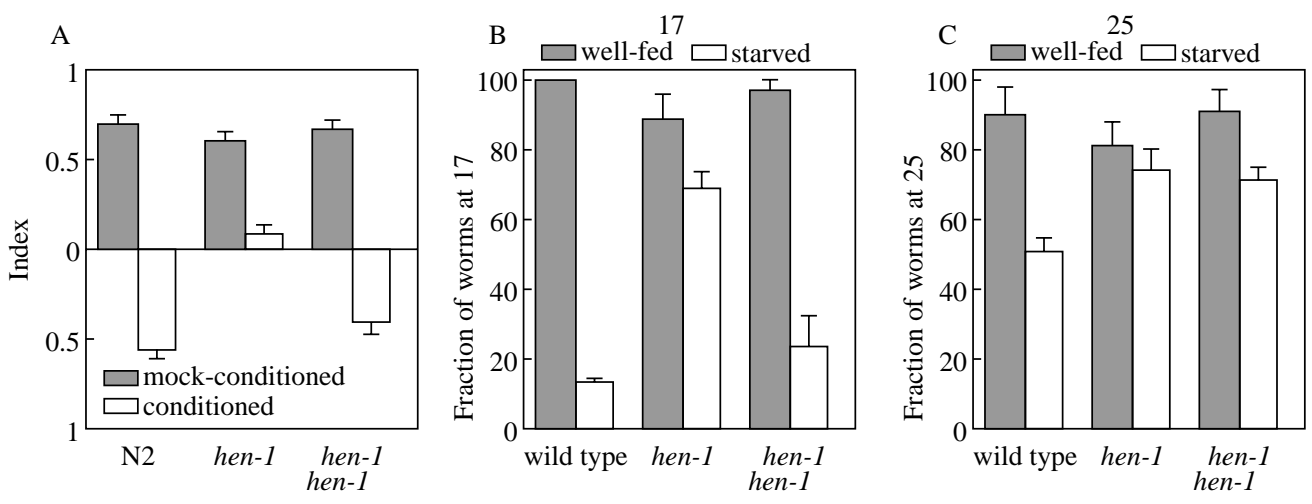

Fig.2 hen-1 mutants show defects in two types of learning paradigms ${ }^{11)}$. A : Chemotaxis toward $\mathrm{NaCl}$ of wild type and hen-1 animals conditioned without food and without $\mathrm{NaCl}$ mock-conditioned) or without food and with $\mathrm{NaCl}$ conditioned). hen- $1+$ ) indicates the wild type hen-1 transgene. B, C : Thermotaxis of wild type and hen-1 animals cultivated at $17^{\circ} \mathrm{O}$ B) or $25^{\circ} \mathrm{O}$ C) under well-fed and starved conditions.

の刺激の対提示後の学習にも異常があつた. C. elegans は, 条件付けなどをしないと $\mathrm{NaCl}$ に寄っていくが,餌の ないプレートで $\mathrm{NaCl} て ゙$ 条件付けしたのちには, $\mathrm{NaCl}$ 避(るようになる13). hen-1 変異体では, 条件付けをし ないときの $\mathrm{NaCl}$ の化学走性は正常だが, 条件付け後 の走性の変化が小さいとがわかった (Fig.2A). また, C. elegansは, 飭が十分にある条件で育つと, 弚の温度 を好み正の温度走性を示すが, 同じ温度て飢餓を体験 すると反対に光の温度を忌避するようになる9), 14) (毛利, 森 私信). hen-1 変異体は, 通常の温度走性に異常はな いが, 飢餓体験後にも温度走性に変化がなかった (Fig.2B, Fig.2C).これらの条件付けには飢餓を用いて いるので, hen-1 変異体か飢餓を感覚しているかを測定 したところ, 飢餓による単純な行動変化には異常がみ られなかった. このことは, hen-1 変異体は, $\mathrm{NaCl}$, 温度, 飢餓兴れぞれに対する感覚受容は正常であるが, $\mathrm{NaCl}$ と飢餓, 温度と飢餓による条件付け後の学習に異常が あることを示している. これらの学習には2つの感覚情 報が必要なことを考えると, 弚れらの情報から記憶を 形成する過程に異常がある可能性もある.

\section{HEN-1の働くメカニズム}

hen-1 変異を遺伝学的にマップした後, 弚の領域の DNA断片の表現型回復活性を指標にして原因遺伝子を 同定した. 产の結果, hen-1 遺伝子は, 分子量約 1 万の分 泌タンパク質をコードしていた. この分子はLDL受容 体リガンド結合モチーフを1つもつが觉れ以外の相同 性はみられなかった. また, 免疫染色により, HEN-1夕 ンパク質は, 感覚神経ASE と介在神経AIY の2対の神 経のみで発現し (Fig.3A), nerve ring とよばれるシナ
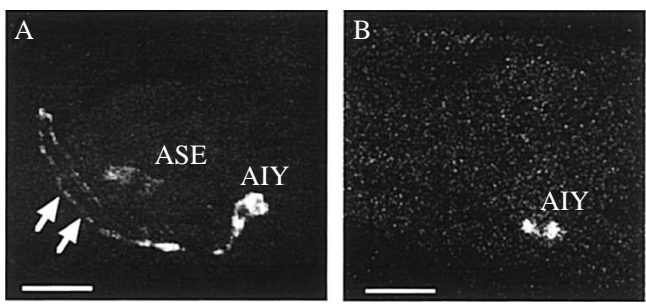

Fig.3 Expression of the HEN-1 protein ${ }^{11}$. Transparent images of wild type A) and unc-104 B) by immunostaining. The arrows indicate punctuated staining of the HEN-1 in the nerve ring. Scale bars indicate $10 \mu \mathrm{m}$.

プスが多い領域の神経軸索で点状に局在していること が明らかになった. シナプス小胞の輸送が行われない unc-104 (KIF1A キネシンホモログをコード) 変異体 ${ }^{15}$ では, 軸索でのHEN-1の局在がみられない (Fig.3B) ことから, HEN-1 タンパク質はシナプス小胞と同じ分 子機構を用いて輸送されていると考えられた。

HEN-1 が発現しているAIY 神経は, LIM タイプホメ オボックス遺伝子变異体 $t t x-3$ では分化に異常がみられ $3^{16)} . t t x-3$ 変異体は, interaction assay において hen-1変 異体と同樣の表現型を示したことから, AIY か感覚情報 の統合に重要な役割を果たしていることが示唆された.

HEN-1 分子の働くメカニズムを解析するため, さま ざまなプロモーターの制御下で野生型HEN-1 をhen-1 変異体に発現させ, 表現型の回復を調べた. HEN-1 が本 来発現しているASEやAIY 神経で発現させた場合だけ でなく, AWC 感覚神経やタッチ神経 (接触刺激を受容 する) で発現させた場合にも表現型の回復がみられた が, 筋肉で発現させた場合には表現型の回復がみられ 

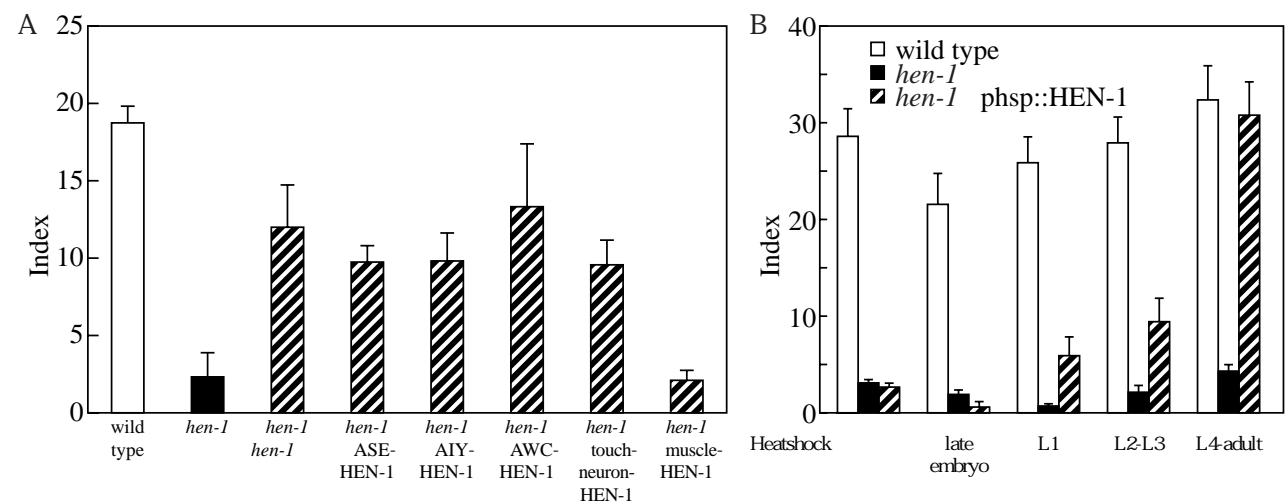

Fig.4 HEN-1 functions cell-non-autonomously in the mature nervous system ${ }^{11}$. A : The hen-1 mutant expressing the wild type HEN-1 protein in specific neurons or muscles was analyzed by the interaction assay. B : hen-1 mutant animals carrying phsp::HEN-1 were heat shocked at various stages and analyzed by the interaction assay at the adult stage.

なかった (Fig.4A). 表現型の回復に適した発現時期を 調べるために, 熱ショックプロモーターの制御下に野生 型HEN-1 をつないだコンストラクトを導入したhen-1 変異体において,さまざまな時期にHEN-1の発現を誘 導し, 成虫での行動を測定した. 神経回路が形成される 胚発生後期や幼虫期に発現させても表現型の回復はみ られず, 成虫期に発現誘導した場合にのみ表現型の回 復がみられた (Fig.4B). これらの結果から, HEN-1は 成熟した神経系において細胞非自律的に機能している と推定され, 神経機能やシナプス伝達の修飾を通じて 情報処理を制御している可能性があると考えられる. 今後, HEN-1 と相互作用する分子の同定や, hen-1 と類 似の表現型を示す変異体の解析などにより, 感覚情報 の統合や学習の分子メカニズムがさらに明らかになる ことか期待される.

\section{6.おわりに}

感覚情報の統合は,“2つの情報から 1 つの出力” と いう最も簡単な情報処理の1つである. このような情報 処理を組み合わせてより高次な情報処理が行われてい ると考えられることから, C. elegansの神経回路のよう な単純なシステムで明らかになったメカニズムは, 哺 乳類の脳などでの情報処理を解析するうえでの基盤と して重要であると考えている. また, 近年C. elegansの 高次行動にかかわる測定系が次々に開発されてきてお り, 今後の解析により高次神経機能の分子メカニズム に迫れるのではないかと期待している.

\section{文 献}

1) Sulston, J. E. and Horvitz, H. R. (1977) Dev. Biol. 56, 110-156.

2) Sulston, J. E., Schierenberg, E., White, J. G. and Thomson, J. N. (1983) Dev. Biol. 100, 64-119.

3) White, J. G., Southgate, E., Thomson, J. N. and Brenner, S. (1986) Phil. Trans. Royal Soc. London 314B, 1-340.

4) C. elegans Sequencing Consortium (1998) Science 282, 2012-2018.

5) Bargmann, C. I. (1993) Annu. Rev. Neurosci. 16, 47-71.

6) Rankin, C. H. (2002) Nat. Rev. Genet. 3, 622-630.

7) Bargmann, C. I., Hartwieg, E. and Horvitz, H. R. (1993) Cell 74, 515-527.

8) Bargmann, C. I. and Kaplan, J. M. (1998) Annu. Rev. Neurosci. 21, 279-308.

9) Mori, I. (1999) Annu. Rev. Genet. 33, 399-422.

10) Hobert, O. (2003) J. Neurobiol. 54, 203-223.

11) Ishihara, T., Ino, Y., Mohri, A., Mori, I., Gengyo-Ando, K., Mitani, S. and Katsura, I. (2002) Cell 109, 639-649.

12) Sambongi, Y., Nagae, T., Liu, Y., Yoshimizu, T., Takeda, K., Wada, Y. and Futai, M. (1999) Neuroreport 10, 753-757.

13) Saeki, S., Yamamoto, M. and Iino, Y. (2001) J. Exp. Biol. 204, 1757-1764.

14) Hedgecock, E. M. and Russell, R. L. (1975) Proc. Natl. Acad. Sci. USA 72, 4061-4065.

15) Hall, D. H. and Hedgecock, E. M. (1991) Cell 65, 837-847.

16) Hobert, O., Mori, I., Yamashita, Y., Honda, H., Ohshima, Y., Liu, Y. and Ruvkun, G. (1997) Neuron 19, 345-357. 
線虫 C. elegansにおける感覚情報の統合と学習にかかわる分子メカニズム

石原 健 (いしはら たけし)

国立遺伝学研究所構造遺伝学研究センター, 総合研究大学院大学遺伝学専攻 助手

連絡先: T 411-8540 三島市谷田 1111 国立遺伝学研究所

E-mail: tishihar@lab.nig.ac.jp 